Canadian University Music Review

Canadian University Music Review

Revue de musique des universités canadiennes

\title{
Music as Social and Cultural Reproduction: A Sociological Analysis of Educational Processes in Ontario Schools
}

\section{Harry Haughton}

Numéro 5, 1984

URI : https://id.erudit.org/iderudit/1013930ar

DOI : https://doi.org/10.7202/1013930ar

Aller au sommaire du numéro

Éditeur(s)

Canadian University Music Society / Société de musique des universités canadiennes

ISSN

0710-0353 (imprimé)

2291-2436 (numérique)

Découvrir la revue

Citer cet article

Haughton, H. (1984). Music as Social and Cultural Reproduction: A Sociological Analysis of Educational Processes in Ontario Schools. Canadian University Music Review / Revue de musique des universités canadiennes, (5), 38-59.

https://doi.org/10.7202/1013930ar

All Rights Reserved @ Canadian University Music Society / Société de musique des universités canadiennes, 1984
Ce document est protégé par la loi sur le droit d'auteur. L’utilisation des services d'Érudit (y compris la reproduction) est assujettie à sa politique d'utilisation que vous pouvez consulter en ligne.

https://apropos.erudit.org/fr/usagers/politique-dutilisation/ 


\title{
MUSIC AS SOCIAL AND CULTURAL REPRODUCTION: \\ A SOCIOLOGICAL ANALYSIS OF EDUCATION PROCESSES IN ONT ARIO SCHOOLS
}

\author{
Harry Haughton
}

\section{Introduction}

This paper is intended to illustrate - by reference to interviews with education officers at the Ontario Ministry of Education, coordinators of music at various Ontario boards of education, fellow music teachers and students - processes through which the teaching of music acts as a process of social and cultural reproduction in Ontario schools. It will argue that the current practice of constituting music guideline committees both at the Ministry of Education and board of education levels is based upon a definition of knowledge that reflects and makes hegemonic the thinking of dominant interests in music and education circles in Ontario, and that also reifies music knowledge. It will further demonstrate that, in being linked to the interests of the state as a powerful social institution, this reification of music-related knowledge is ideological and serves to covertly reproduce established social, moral, and aesthetic values.

Recent scholarship in the sociology of education proposed theories of social and cultural reproduction as well as theories of cultural resistance as ways of explaining how imperatives of the state impact upon the entire field of "school knowledge." Theories of social reproduction (see Althusser 1971; Bowles \& Gintis 1976; Poulantzas 1973) have emphasized processes of schooling as reflecting ultimately and in a rather passive manner wider social processes, while different theories of cultural reproduction (see Bourdieu \& Passeron 1977; Bernstein 1977) have emphasized the symbolic and linguistic means through 
which the wider social domination of schooling is conceived as being achieved. In contrast, theories of cultural resistance (see Giroux et al. 1981; Willis 1977; Hall \& Jefferson 1976) emphasize the manner in which students and teachers may act positively rather than passively in terms of the meanings that life in school holds for them, at times paradoxically aiding processes of social and cultural reproduction while at the same time resisting the social and cultural status quo. With resistance theory, people are not regarded as passive ciphers operated on unilaterally by monolithic social forces. Societies and cultures are conceived as dynamic and dialectic processes. As Hebdige (1979), Willis (1977), Brake (1980), and Whitty \& Dabies (1981) have demonstrated, the reproduction of culture also reproduces resistance.

It is in these dialectic terms that the role of music as an agent of social and cultural reproduction in processes of schooling has to be understood. However, arguments concerning social and cultural reproduction apply as much to questions of ethnicity as they do to questions of class stratification. Olsen (1980) and Titley and Miller (1982), for example, have found relationships between class and ethnicity in Canada to be so strong as to be almost indistinguishable. Olsen in particular finds that reproduction mechanisms answer to the structure and functioning of the state elite and concludes that among the roles that still tend to be appropriated by members of the two charter groups are the elite roles of the state system, a reality that contrasts rather starkly with the imagery of multiculturalism. This understanding of ethnic stratification functions in turn to underline a particular understanding of responses by Canadian youth to the class and ethnic dynamics of schooling. It has, for example, been found (see Haughton 1983) that the musics and personnel of the so-called "ethnic minority" Canadians are systematically and consistently excluded from influence on the definition of music knowledge in Canadian classrooms, given the educational system's definition of what counts as "musical knowledge" in schools. A major but ancillary theme of this paper is the manner in which the status quo of ethnic stratification is maintained and reproduced in part in Ontario through music education policies.

One point of departure for this paper is the work of Vulliamy and Shepherd in the sociology of music education. Vulliamy (1977) has argued that music allows for the preservation of certain ideological notions important to the educational system, 
and cites the roles of the mass media and selective government subsidies in imposing upon all the cultural capital of the middle classes as the only legitimate musical forms. Bourdieu and Passeron (1977) refer to this as "violence symbolique," the desecration of the cultural symbols of a people for those serving the interests and tastes of those with power and influence. Shepherd (1983) expands upon this notion, suggesting that the processes of school music teaching in Ontario goes beyond the mere legitimation of a dominant musical ideology and contributes to much more pervasive ideologies underpinning capitalist societies. Shepherd (1982) wisely cautions against the dangers in asserting boldly the existence of homologies between musical structures and social structures without a corresponding theoretical analysis of how such homologues are produced. However, he does an excellent job of establishing such parallels, arguing in particular that an insistence on literately mediated notions of "what counts as music" leads to a music curriculum that downplays considerably the immediate, the personal, and the social in the lives of students. He furthermore contends that, "it is not difficult to see how phonetic literacy and typography have facilitated the tight, reductionist control and manipulation of knowledge in capitalist society and so, in turn, the progressive dehumanization of people" (Shepherd 1983: 38). As Shepherd and Vulliamy have argued, the marginal status that music seems to have among other subjects in the curriculum functions to conceal its real effect (and perhaps its real purpose) as part of the school knowledge granted legitimation by the educational system:

... despite music's marginal status on the school curriculum as compared with high status academic knowledge, we contend that the contribution that it makes to the reproduction of capitalist ideology is significantly greater than this marginal status suggests (Shepherd \& Vulliamy 1983: 10).

The value of a critical approach to music education policies that link curriculum and teaching practices to the imperatives of the state on the one hand, and the imperviousness of many music educators to music's role in social and cultural reproduction on the other, are both attested to in an interview with an education officer of the Ontario Ministry of Education. A principal concern is the maintenance of the cultural capital of those with power and influence: 
Education Officer:

We are concerned primarily with the transmission of the cultural heritage of Canadians. We like to know that our student's performances reflect a high standard of work. The garbage music that is now in students' heads has come about at the same time that immigration and increased technology have both mushroomed in Canada.

Researcher:

Are you saying that immigrants to Canada are responsible for having brought the music which you term "garbage," and that contaminates that which constitutes the "pure" cultural heritage which you wish to transmit? At the same time, are you not denying the Canadian-ness of those "immigrants" who are now Canadian citizens?

Education Officer:

That is not what I meant. I simply mean that our business, mine and yours, is to stick to the business of music and forget all the other stuff about how groups relate to one another. We just need to produce good music out of students and leave the social theorizing to others. Kids do not even think about that, any way (Interview, January 1982).

\section{The Research}

a) The Graded-Guided Approach to "Music Literacy"

One day while we were sitting down to the business of producing Grade 7 and 8 music guidelines for the teachers in our Board, I spoke out against a section which had been written in previous guides and which I had questioned with other music teacher colleagues before receiving the appointment to the curriculum making body itself. My criticism related to a section entitled The Twelve Steps To Music Reading, a detailed outline of how teachers should have their classes acquire musical literacy by a progression through each of the steps.

I had seen many excellent musicians (e.g., those who entertained tourists in the hotels of Jamaica with the island's native folk songs) who could not read a single note of music in notated form. I had worked with very successful recording groups who could not read music if their lives depended on it. I had read that the music of India - including its "classical" music - follows an oral-aural tradition in which each performer has to add to the original piece of music. I know, therefore, that systems of notation function to "freeze" composing, and do so as one aspect of the social construction of "knowledge." 
In reply to the objections I tried to raise and the viewpoint I had hoped my colleagues would have welcomed, I was reminded that we were preparing a document for a school, and that literacy was what schools were about, not "experience." A literacybound orientation to music essentially negates the experiences expressed in music that do not receive such expression through notated and "read" sound symbols. By providing a mold into which musical experience must fit and through which it must be expressed in order to receive legitimation by schools, the literacy approach negates the emotions of some students, leading to alienation of these pupils, and preparing the background for much of the "culture clash" reported in Vulliamy and Lee (1980) \& 1982).

Such approaches to education (and music education in particular) become the means by which consent and conformity are also accompanied by a rejection of the former culture as backward or underdeveloped. As one girl from Vietnam told me:

We not like this music in school here. In our school we make songs with the teacher and we feel good. Here we make the sounds the book want us for make, and the teacher feels good. We feel good too about pleasing the teacher, but not how music means. Music is for feel good inside, not for pretty picture outside but still feel rotten inside (Interview, November 1981).

\section{b) Student Composition and Teacher Response}

One of the concerns I had in approaching the interviewing of the Coordinators of Music resulted from an earlier observation of mine that despite expressed interest in student creativity, their compositions were often not regarded as good enough for performance. In addition to that, even some students who had composed and performed their compositions on local community television were told that their songs were not of a sufficiently high caliber for offering in public. One girl reported having been scolded by the teacher after one such performance, the teacher expressing concern about his "image" when she told the television audience that he was her music teacher. She seemed so upset that I asked whether she would still write songs. She replied:

Well, I'm not even so sure I would write again. As a matter of fact, maybe I would, but not as long as I am in that stupid school. You get the impression that they really want you to try and make up something, but if you do they put you down for it. 
What they really want is the old Beethoven stuff which nobody wants to hear except the old folks and the senior citizens who think they are in high society and who want to preach to us all the time and sell us a load of good culture. Right? But our generation doesn't go for that stuff. We listen to the music of today's stars. We sing from how we feel. That is why their music and the music we do in school is so false and deadsoundin' and kids don't like classical and all that stuff. It does not really tell exactly how you feel, but it tries to make you imagine that you feel different from how you really feel. It is like telling us how to pretend to be good. I used to respect $\mathrm{Mr}$. but now I know he's just as crappy and as phony as the rest of them (Interview, November 1981).

This negation of student's compositions was found among Coordinators of Music as well, also concerned about "images."

The following conversation generally sums up the response and attitudes of these Coordinators:

Researcher:

Do any of the choirs of instrumental groups perform songs on pieces that any of the students themselves have written.

Coordinator:

No! I didn't think that was what you were after. At least I do not know of anything like that happening in our schools. I do not even know that there are teachers who could write pieces which parents would appreciate, especially band music. I should hope that any such a public presentation would first be submitted to proper and careful scrutiny before the actual presentation. We do have in the elementary schools occasions when students group together and make impromptu compositions for ten minutes or so, and then present them to the entire class. They have enormous fun doing that. Sometimes they are good enough that the teacher writes them down and displays them on bulletin boards around the school.

Researcher:

If they are good enough for a visual display in the school, why couldn't they be performed by the very students, maybe, who produced them, or why could the students not be taught to write the music themselves? Couldn't they even make up their own sets of symbols and have that highlighted as part of the act of creation?

Coordinator:

Two things respond to that. In the first place - and we discussed this earlier - I am concerned that teachers do not 
know enough music to do the kind of job that needs to be done in today's schools. I wish they did. Secondly, since the music department tends to be seen as the chief public relations agent of the school, we have to be very careful to present an image of respectability - or rather an image that parents respect - in what we do. It is one thing to make up their own music symbols which they can interpret. It is another thing to convince parents that the music their children are getting is one that is used and respected all over the world. You know how parents or people in general are. They are very quick to criticize us and we therefore have to try to be safe and at least satisfying in what we do (Interview, December 1981).

It is important to take note of the fact that in the mind of this (and many other) Coordinator(s) there was an objectified meaning to "knowing" music. In this view, music knowledge is reified. It is something "out there" to be "known," and most teachers - according to this Coordinator - do not "know" enough. Music knowledge is thus externalized and to "know" it is to alienate oneself from one's true feeling. The ability and desirability of expressing this deep-down feeling, however, is suppressed by the concern (at different levels of the system) to present the proper "image."

I have heard thousands of similar responses to the school's music and the music that students seem to find both available and enjoyable outside of school. The general stance of the school - expressed through the music teachers - seems to contribute to a low self-concept in students regarding music as knowledge that they get from the schools. In the long run, this feeds into a self-fulfilling prophecy observable in what Shepherd (1983) describes as the students' voting with their feet. They leave the music program as soon as they can, or never get involved with it to begin with, especially when they have their transistors to provide them with the musical knowledge they crave, as opposed to both the negation of experience and the experience of negation which seem to accrue from school music.

\section{c) Extent of Music Guidelines' Usage in Classrooms from the Perspective of Coordinators of Music}

There was an obvious difference in what different Coordinators meant by "following the guidelines." For some it meant following the directives with extreme exactitude, while for others it meant having an idea of what was wanted and going 
there in the way the teacher could best travel, provided that there was clear evidence that the teacher's plans and methods did not contravene guideline material. There was consensus, however, that guidelines were being followed. It was in an attempt to implement the content of the guideline document that most teachers who were adjudged "ignorant and lacking in knowledge of music" were detected. Some teachers, like the one reported below, admitted to dependency on the guideline, but were able to rationalize the dependency as follows:

Well, what else have we got? We have to have some way of knowing what to teach to the children. I mean, there is nothing wrong with that. It happens in Science, in Math, in the language arts. There has to be some standardization of instruction. I have never been on a curriculum committee, myself, but I don't need to be. I trust the wisdom of the people who have been chosen to do the job. I wouldn't know what to do without the guideline. I can accept that the ideas are not always workable, but given the circumstances of the curriculum workers, I see them doing a damn good job. Someone has got to tell us what to do. I myself don't claim to be an expert. I need the wisdom of someone who has done this for long enough to know how to do it, and how to advise me in providing good lessons for my kids. I just wouldn't know what to do without the guideline. What I do not know at first reading, I find I can understand better at workshops, or there is always another teacher somewhere who knows what the guideline says about how to get the children to enjoy themselves and make the lessons fun (Interview, July 1981).

What has begun to emerge is that the teachers have different levels of skill in the technical aspects of music (e.g., ability to play an instrument or to sing well enough to avoid being laughed-at by students). This was revealed from my own observations. Some Coordinators, however, do not make allowances for the different backgrounds of teachers, and expect that all music teachers should display a certain behavior to which they could apply the label "having a knowledge of music." The more such a lack is detected, the greater the desire for those teachers to stick to the guidelines, as is revealed in the following interview:

That is the whole problem. They tell us they try to follow the guideline. They all say they do. Yet my consultants and I find that they have no knowledge of music to enable them to do a good job. I really question the quality of their pre-service 
training. We can't leave them up to do what they want to do. The children would suffer. We therefore try to make the guidelines so simple, sometimes we ask just how we are perceived by any other Board's staff who read our documents for the simplicity we put into them in an effort to help our teachers. And yet we do not seem to be able to help the vast majority of them. That is the crux of the whole matter. They are required to teach by the guideline, so whatever they do can be seen as some reflection of us and the programs we plan. From speaking with my consultants and some of the teachers who I sometimes get a chance to see, I know that they all use the guidelines, but God, do they ever need help! We give to our principals some guidelines to help them assess a teacher's performance in music, but since most of them seem not to know their --- from their heads, it hardly helps. Sometimes I wish we did not have to spend the time writing the guidelines, but those very teachers ask for it, for it is a legal requirement, and they wouldn't know how to carry a message - never mind a tune -without some such help. I really think "Yes." They all try to follow the guides and teach according to what's there but they need all kinds of help which gets harder and harder to come by (Interview, December 1981).

One negative case I encountered provided some rather interesting data. There was a teacher who was so good that his school kept winning first prize in all Festival events in the borough, and this brought him to the attention of the Music Department. He was visited by the consultant for his school area. She praised him for the impressive display of trophies in his showcase, but remonstrated with him, after observing him for a morning session, for not following the guidelines in terms of the progression that it recommended for teaching specific concepts. He was also given a very strong reprimand by the principal after she had reported to him her finding of this unorthodox methodology. The principal, so he told me, though glad for the trophies, also agreed that guidelines are to be followed, and now that he had "made his name," maybe it was time for him to begin really teaching some genuine music.

It is apparent that this principal had his own feelings regarding what counts as musical "knowledge." Though he was glad to have the teacher give his school an extremely good public image, he too was ready to concede that what this teacher had been doing was not really "music." The Coordinator also makes it clear that it is not so much what is taught that is important from 
her perspective. What's of the essence is whether or not the right rules (as laid down in the guidelines) are being followed. This replicates Anyon's (1981) finding that there is a style of pedagogy in which "knowledge" is defined more by "following the right steps" with little regard for accuracy or impact of content. Here is an excerpt from an interview with the wayward teacher:

Informant:

Well, one day I had a visit from the Music Consultant who had never been in to see my program before. Her visit ended before long, with a promise to bring me the latest copy of the proper music guidelines which I should be using. She complained that my methods were unorthodox and that I ought to be following the guidelines more closely even if it meant that $I$ had to find the time to take Ministry courses.

Researcher:

Why, weren't you aware of the guidelines?

Informant:

To my mind I was following them in that I was using my own initiative to plan for my children as I saw fit to do. My students were very happy with what we were doing, as also were their parents. As least the children got the feeling that making music could be fun while they acquired the skills of playing on the instruments.

Researcher:

What did she think of the many trophies in your display case? Does she not know of the festival, or doesn't she think anything of it?

Informant:

Yes, I think she is aware of it, but the Board does not seem to have very fixed ways of doing things, and wants things done in it s own way. It is not the end product that is important to them, it is the rigidity with which you make sure to follow what they tell you to do.

Researcher:

Why do you say that?

Informant:

Well, before I came here I was in another school where the principal was a real stickler for doing things by the book. He would always be calling in the Consultant to make sure things were being done as the Board guideline said they should be 
done. It was very very frustrating. Sometimes he would wait until the day before a performance and then call this guy to have him tell you what was wrong, and then you were expected to fix it before the following day, though you got no extra time in which to fix anything, and just as well, for then it was too late to change much with children that age.

Researcher:

But why did he feel that you were not following the guideline in the first place? How right was he in feeling that way?

Informant:

Not right at all. I'd like to think that I am following at least the spirit of the guideline which has to allow for a bit of teacher initiative. After all when one does music all day, one cannot be expected to present any two lessons even to the same grade level in exactly the same way. School administrators and program supervisors are too far removed from the reality of classrooms except to enforce strict obedience to people who have more facility than ability to rule.

Researcher:

What exactly do you do that you find to be so different from what other teachers of music do in classrooms?

Informant:

Well, in the first place, when I went to school in England we had a very fine teacher who always got packed houses when he put on a concert, and I really believe in his methods. He said that any child who knew his A B Cs could be taught to read music. I have been copying his methods, but the people here tell me I should be using Kodaly's method, starting with pentatonic songs. I do not believe in the pentatonic songs, for the scale which the children knows is do, re, mi, fa, so, la, ti, do, and that is more than five degrees as is in pentatonic. I believe in starting with what the children come to you with and building from there. Since they come to me knowing eight degrees in the scale, for me to go back to five is taking a step back from where they already are. Nothing is wrong with the Curwen scale. I don't know what you used in Jamaica, but we used Curwen in England. Kodaly isn't that much different, so I do not see why I can't stick to what I am comfortable with.

Researcher:

Well, Kodály is not essentially about scales. I think all he has done is to have suggested that the pentatonic scale lends itself to harmonizing without a sense of anyone having been discordant, to the same extent as would have applied using 
Curwen's diatonic major scale. By the way we used Curwen in Jamaica, too.

Informant:

I still believe in the English way, but if that is what they want I guess that's what I'll have to do.

Researcher:

Are you going to do the courses as was suggested by the Consultant then?

Informant:

You know how it is, you don't fight the system. If you don't do what superiors recommend, you get a bad report from them. Depending upon what your aspirations are, one could be doing a stupid thing to resist the forces that have the power to hurt you.

Researcher:

That is not the purpose of a resource person like the Consultant, though. They are there to support you and give you ideas they have picked up from conferences and from workshops they themselves attend.

Informant:

This lady wasn't exactly suggesting. She was telling me what she wanted me to be doing, and how to be doing it. In any case, I am not going to wait around to find out what she means by getting a bad report. These are not the job-security days of some time ago. When you have been given an indication that someone in charge wants things done in a certain way, you get it done if you still like to eat. Some children inevitably suffer, but these days you follow commands or risk stiff penalties. I believe in what I believe in, but I'll do what those people want, and how they want it done. It does not pay to try to fight the system (Interview, April 1981).

What we have here is an example of resistance that finally acquiesces, probably because it did not perceive itself to be "resistance" in the first place. This teacher was confident that he was following the spirit of the guideline document. For the Consultant, however, it was the letter of the guideline that was being ignored, and that therefore meant that the teacher's "unorthodox" approach began to constitute resistance to hegemony, and for this he had to be brought into line. By attempting to free his students from the rigidity of the guidelines, he had exposed himself and his pedagogy as elements of the music education microcosm that needed to be made to 
adapt to the pedagogy and politics of the musical mainstream. He knew that maintaining an oppositional code and practice to that of the dominant ideology might lead nowhere. Unlike Willis's "lads" (see Willis 1977) he would much rather capitulate to the dominant ideology than maintain his resistance.

It is important for us to notice, finally, that the Coordinator had no doubt that the guidelines were being followed. It was the fact that they were being followed by people who "had no knowledge of music" that really worried her. As she herself observed: "I know that they all use the guidelines ... but do they ever need help." We have seen also that music leadership is more concerned with how well teachers follow the rules than what content they impart. The negative case teacher did not follow the rules well enough to please his superordinates, but even he saw himself following the rules. There was no refusal to do so.

\section{d) Teacher Perceptions of the Basic Issues Regarding Music Education and the Music Curriculum Guidelines}

Interviews with teachers were very informal and unstructured. The questions were not stated exactly the same way for each respondent, so the answers cannot with any real significance be reported in tables. The synopsis of the general responses will therefore be somewhat anecdotal. The teachers were asked, for example, to comment on the notion of pooling together teachergenerated guideline pointers at the classroom level as opposed to the current "curriculum by the expert" designed in some office.

The great majority of the interviewees disagreed with the notion of curriculum by "experts" at either the Ministry or the Board level. Of this number, most expressed the wish to have curricula constructed at the level of the classroom "where," as one teacher put it, "the rubber hits the road." Some of the reasons given for that observation included comments such as:

Mrs. T.:

A more meaningful experience will result if approached with this perspective.

Miss J.:

There should be more emphasis on what the kids are listening to and what they are interested in.

Miss E.:

I endorse the notion very strongly. All guidelines should be written from the classroom. 
Mr. F.:

There should probably be some Board ground rules, but the writing and working out of details should be left to the classroom teacher.

Another question dealt with the issue of whether they had had a perception of there being a proper school music and nonschool music during their own schooldays, and if so to comment briefly on what the differences were. All reported that there was a great difference. Some of their comments are recorded here:

Mrs. N.:

Yes, there was a big difference. In school we only sang. There were only "kids'" songs, and no music that was current.

Mr. W.:

Non-school music was much more enjoyable.

Miss K.:

Yes. Grade school music was all group singing, whereas nonschool music was "free form," bands, etc.

Mr. K.:

I couldn't "do" music, and therefore didn't pursue it.

Mrs. H.:

A big difference. Non-school music was treated as fun. School music had too much of an academic content, and, depending upon what you mean by "learning," I learned a lot more outside.

These interviewees were also asked to state what changes, if any, they would like to see at the Ministry of Education as well as at their own Board level as sites of curriculum production. A few reported having no direct knowledge of the official procedure for generating the guideline document at eight of those sites. They simply knew that guidelines come from those places and that they were supposed to teach from them. The vast majority claimed knowledge of the process, and expressed a desire to see changes in the direction expressed:

Mrs. G.:

I'd love to see more curriculum production at the school and Board level, and less at the Ministry level. Curriculum guidelines should be a collection of ideas and techniques in current use from as many people as possible, to allow teachers to extend their presentation of music in the classroom. 
Mr. P.:

I'd love to see increased funding for more personnel and equipment.

\section{Mrs. A.:}

From my small knowledge I think too often music is presented to the students with little consideration for what interests them. I have yet to meet a student who did not like music, but I have found lots who disliked the music that they got in the school and the way it was presented to them. They disliked the subject.

It seemed clear to me from some of those comments that there was a perception of biases in the direction of those who write the guideline documents and what was further perceived to be their own inadequate preparation to teach to the interests of students. This prompted me to ask the question: "Have you detected any dissonance between the content of your own training to be a music teacher in Ontario schools and the realities of a classroom in terms of finding that what the children want -even as a compromise with you - is outside of what you were specifically trained to teach?”

The overwhelming majority of these current teachers of music reported feeling inadequately prepared for the classroom, leading some to express the opinion that curriculum planners and teacher-training bodies are "out of touch." Here are some of their comments:

Mr. R.:

There is a need to accept that both children and parents want the child's education to be relevant to today's standards, not that of some time ago when present "officials" were in school. Each year I have been coming to summer school, hoping that one of the times I'll get what I seem to need to be relevant to my students' interests and requests in music classes.

Mr. J.:

Yes. I have come to realize that theories need to be tested with changing times and circumstances. I always knew this, but I don't see it happening as much as it should.

Miss O.:

Yes. Teacher college training had little bearing on changing curriculum. Training focussed more on theory rather than on the practical. It's difficult out there with today's kids. 
Mrs. C.:

The pendulum swings, and my professional development has been on-going. I have had to struggle to maintain a balance, and official teacher-training was a real fiasco. It did not relate to what I found in school. I have had to take private lessons in order to cope.

There was general dissatisfaction with the method by which the curriculum document is currently constructed. Most teachers who expressed this feeling wanted to see more action at the classroom level where the realities encountered by teachers in the day-to-day administration of a classroom can impact more upon the practice. Wanting to change the face of "school music" to reflect greater inclusion of the interest of the students also had some priority. Some teachers felt that current emphases in teacher-training for music are most irrelevant, and that it left them totally unprepared to face the challenge placed upon them in meeting the "real" boys and girls who constitute today's classrooms.

One of the benefits of doing a study such as this is the insight gained into the perceptions of the people who are most directly affected by the curriculum guideline process. By thus allowing us to get a glimpse of the meanings which they read into curriculum documents, more meaningful educational interventions geared to teachers' perspectives are facilitated.

e) Certification Requirement As Potential Ethnic Exclusion

One of the ways in which Canadians bearing particular cultural backgrounds are systematically denied influence upon the musical culture of schools lies in the certification required for certain positions (e.g., Coordinator of Music) in the Ontario system. One highly successful music teacher from the West Indies informed me in the context of a very informal interview that:

There are some requirements demanded of teachers who wish to upgrade themselves within the school system, which discriminate against immigrants to Canada. Take my case, for example. I came to this country with an undergraduate fine arts degree in music from the University of the West Indies. Having been employed in music here, I thought of upgrading my qualifications. I did the Ministry's Vocal and Instrumental Additional Qualification courses, but I have been debarred from doing the "Specialist" course because the University of 
Toronto's Faculty of Education refuses to grant equivalency status to my undergraduate degree, primarily because of the university from which it was obtained. They insist that it is not the equivalent in content to a degree obtained in Canada. To me this is most unreasonable to expect, since it is not the function of the University of the West Indies to train students for the Canadian classroom. The reverse is also true. The reason I am mad is that with that stipulation I can never even hope to be a Head of Department, since the "specialist" certificate is a prerequisite for that position. Despite how good I am, I shall never be able to earn the professional respect I deserve. If that is not discrimination against my cultural background, you tell me what is. That should never be allowed to happen in a nation boasting cultural plurality (Interview, October 1979).

It is important to the thrust of this paper to note that the "specialist" certificate of which that teacher spoke is among the requirements that a Coordinator of Music must have in order to be considered qualified to apply for such a position. This teacher could be very good at the subject, and could begin to be an influence upon the thinking that informs curriculum thought and curriculum policy in music education in Ontario along the dimensions that are central to this study. As that interview illustrates, however, there are current restrictions built into policy regarding the backgrounds of Canadians who are nonnative to the culture.

In terms of being able to contribute to Canadian music education in the leadership role as defined earlier in this study, this teacher will have to be satisfied to be seen as second class at best, having been effectively screened out of the sphere of influence and leadership of policy. One would expect that the completion of the Part I and Part II sections of the Ontario qualification would serve to satisfy the requirement for admission into the "specialist" course, since that is just another summer course like the first two parts. I checked this with the Faculty of Education's music department, and the teacher's story was authenticated. The Ministry of Education expressed sympathy for the teacher, but explained that since that was an internal stipulation laid down by that particular faculty, they were powerless to intervene. They advised that I inform the teacher to try another university which did not have that requirement and would honor the Ministry's official recognition 
of her qualification. When I spoke with her on a subsequent date, she reasoned that:

... It would not help, don't you see? I do not want to get second-rate qualifications. What the Ministry is suggesting is that there may be universities of lesser stature that would accept me without any qualms, but that is my point. I could still be faced with having inferior qualifications, for the implication is that the University of Toronto's Faculty of Education is more demanding and therefore a better university from which to obtain qualification. If I happened one day to be in competition with someone who had obtained qualification from U. of T., and if all other variables were equal, even the very Ministry - by implication - would consider the other person better qualified and hence endorse the selection of the other person. I will not settle for second best. I want the very best and highest available. Only that is good enough for me.

We have touched upon a very delicate point that may seem trivial to some, but one which reveals the essence of much of what I have stated to be my central concern. There are, undeniably, ways in which cultural background functions to exclude not only students but teachers from full participation in Canadian society. When this obtains, multiculturalism remains a prescription for the Canadian experience of some, and not a description of it.

\section{Conclusion}

An examination of the literature on the philosophy of music education in Ontario schools, discussions with education officers at the Ministry of Education, with Coordinators of music at the several school boards, and with practising colleagues reveals a commonly held view of music as "reified knowledge." Treated as such, music functions chiefly to maintain and reproduce a system of social control mediated through cultural symbols. Treated as the dynamic interpretation of lived reality and the site of the production of meanings, it could also become a potential site of resistance and praxis. In other words, despite the traditional view of music as a time filler on the roster of curriculum content areas, there is a more subtle possibility than is readily apparent that effective but invisible control can be achieved through the instrumentality of school music. 
Among young people in general music is seen to occupy such an import place in their lives that some sociologists (e.g., Frith 1980; Vulliamy \& Lee 1980 \& 1982; Shepherd et al. 1977; Shepherd 1983) propose music as the agency through which many young people give meaning to their lives. Consequently recent work in the sociology of education has treated a critical assessment of music education from the perspective of analyzing what counts as valid musical knowledge in the school curriculum as the site of the production and legitimation of experience.

Johnstone (1976) and Shepherd (1983) are among the very few scholars who have done this kind of research in Canadian education. Both researchers have discovered that no other discipline makes the distinction between the culture of the school and the culture of the pupils so graphically apparent as music education. They also have found that school music curricula tend to be characterized by a preponderance of "serious" and "light classical" music, while youth culture formulates and expresses itself primarily through the music commonly referred to as "pop" or "rock."

We have made mention in this study of the ways in which the school is still observed to perpetuate the legitimation of "serious" and "light classical" music as being somehow better than "popular" or "rock" music. This pattern of legitimation reveals some of the assumptions of those responsible for the production of musical knowledge in schools. When a musical genre is presented as the only one truly worthy of the label "music," there is no need to spell it out and to engage in long (if any) discussion of it. As Shepherd observes, "one simply reproduces [the social and musical environment], and communicates personally and intuitively with it" (1983:30). However, by placing the label of legitimacy on specific forms of musical experience as "knowledge," the possibility is created for the negotiation of legitimacy of other forms of musical experience.

If the lived musical experiences of students do not find either legitimation or expression within the musical culture of the school, then the way is open for certain resistances which may or may not effectively change the situation for the student. The initial failure to experience legitimation will generate resistances that can be either successful (if they result in change) or unsuccessful (if the status quo persists despite such resistance). Then again, as in the case of Willis's "lads," resistance could be 
used as proof of the unworthiness of the human types promoting certain musical tastes and styles. Dropping out of school may be one of the chief (and perhaps most blatant) modes of overt resistance. Students know that they will be no farther ahead either in school or out of school. However, absence can be scored a temporary victory. 


\section{REFERENCES}

ALTHUSSER, L.

1971: Lenin and Philosophy and Other Essays. New Left Books. ANYON, J.

1981: Elementary Schooling and Distinctions of Social Class," Interchange, XII/2-3, 118-32.

BERNSTEIN, $\mathrm{B}$.

1977: Class, Codes and Controls. 3 vols. London: Routledge \& Kegan Paul.

BOURDIEU, P. and PASSERON, J.

1977: Reproduction in Education, Society and Culture. New York: Sage Publications.

BOWLES, S. and GINTIS, $\mathrm{H}$.

1976: Schooling in Capitalist America: Educational Reform and the Contradictions of Economic Life. London: Routledge \& Kegan Paul.

BRAKE, $M$.

1980: The Sociology of Youth Culture and Youth Subcultures.

FRITH, S. London: Routledge \& Kegan Paul.

1978: The Sociology of Rock. London: Constable.

GIROUX, H. et al.

1981: Curriculum and Instruction: Alternatives in Education. Berkeley, California: McCutchan.

HALL, S. and JEFFERSON, T.

1976: Resistance through Rituals: Youth Subcultures in Post-War Britain. London: Hutchinson.

HAUGHTON, H.

1983: "Social and Cultural Reproduction in the (Music) Curriculum Guideline Process in Ontario Education: Ethnic Minorities and Cultural Exclusion." Ed.D. dissertation, Ontario Institute for Studies in Education.

HEBDIGE, D.

1979: Subculture: The Meaning of Style. London: Methuen.

OLSEN, D.

1980: The State Elite. Toronto: McClelland and Stewart.

POULANTZAS, $\mathrm{N}$.

1973: Classes in Contemporary Capitalism. London: New Left Books.

SHEPHERD, J.

1982: "A Theoretical Model for the Sociomusicological Analysis of Popular Music," Popular Music, No. 2, 145-77.

1983: "Conflict in Patterns of Socialization: The Role of the Classroom Music Teacher," Canadian Review of Sociology and Anthropology, XX/1, 22-43. 
SHEPHERD, J., VIRDEN, P., VULLIAMY, G., and WISHART, T.

1977: Whose Music? A Sociology of Musical Languages. London: Latimer New Dimensions; reprinted New Brunswick, N.J.: Transaction Books, 1980.

SHEPHERD, J. and VULLIAMY, G.

1983: "A Comparative Sociology of School Knowledge," British Journal of Sociology of Education, IV/1, 3-18.

TITLEY, E.B. and MILLER, P.J.

1982: Education in Canada: An Interpretation. Calgary: Detselig Enterprises.

VULLIAMY, G.

1977: "Music and the Mass Culture Debate," in Shepherd et al. (1977), 179-200.

VULLIAMY, G. and LEE, E., eds.

1980: Pop Music in School, rev, ed. London: Cambridge University Press.

1982: Pop, Rock and Ethnic Music in School. London: Cambridge University Press.

WHITTY, G. and DABIES, D.

1981: The Politics of Cultural Production: Society, Education, and WILLIS, P. the State. Milton Keynes: Open University Press.

1977: Learning to Labour: How Working Class Kids Get Working Class Jobs. Farnborough: Saxon House. 